\title{
THE INFLUENCE OF FEMALE LEADERSHIP TOWARDS PERFORMANCE: EVIDENCE FROM WESTERN EUROPEAN FINANCIAL FIRMS
}

\author{
Cong-Duc Tran* \\ Ton Duc Thang University, Vietnam \\ Ly Pham T. Minh \\ Ton Duc Thang University, Vietnam \\ Jo-Yu Wang \\ National Formosa University, Taiwan
}

\begin{abstract}
Does the appearance of women at the executive position in the boardroom make any differences in firm performance, especially in the financial sector which is well-known to be a male dominated sector? Inspired by that question, our study aims to explore the influence of female leadership in firm performance. We investigate this relationship from a comprehensive dataset comprising of 310 listed financial institutions from 21 Western European countries. The endogeneity concerns were removed using a Two stage approach least square (2SLS) and Generalized method of moments (GMM). Critically, we demonstrated that women's appearance at alternative managerial levels, including the chairperson, executive, and total female directors in the boardroom, negatively influences both firm accounting and market-based performance. We further explore that the percentage of women in the boardroom (excepting non-executive female directors) has a negative impact on performance only in low-performing firms. Our findings argue with previous studies which encouraged more involvement of women at higher managerial levels. We believe that women's unique characteristics are addressed to alleviate interest behavior, but they tend to reduce the performance of financial firms.
\end{abstract}

Keywords: Gender Diversity, Board of Directors, Corporate Governance.

Received: 29 July 2019

Accepted: 10 May 2021

https://doi.org/10.33736/ijbs.3731.2021

\section{INTRODUCTION}

The twenty-first century has been marked as the new era for unprecedented changes stating the higher role of women around the world. However, there is a shortage of research that considers the contribution of female leadership in hierarchical organizations, which is well-known as a field has been dominated by male counterparts. Notably, the proportion of female directors is only 20 percent in 2019, whereas 5.3 percent of the chairpersons are women. Even in developed countries,

\footnotetext{
* Corresponding author: Faculty of Business Administration, Ton Duc Thang University, 19 Nguyen Huu Tho Street, Tan Phong ward, District 7, Ho Chi Minh City, Vietnam. Email: trancongduc@tdtu.edu.vn
} 
the ratio of female to male leaders is very low. Specifically, Hoobler et al. (2018) show that only 4 percent of a total of 46 percent women in the United States workforce hold chief executive officer (CEO) position and 16 percent are directors in the Fortune 500 companies. Although the European Commission has adopted several regulations to encourage gender equality in the boardroom since 2010, the progress is not that visible. Jourova (2016) mentions that only 23.3 percent of directors are women in European companies. Furthermore, only 7 and 5.1 percent of the largest European listed companies in Europe have female chairpersons and CEOs. Of which, only 16 and 20 percent of directors and executive committees are women in the financial sector.

In the literature, despite the increase in research towards the relationship between female leadership and firm performance, the findings are considerably inconclusive (Gordini \& Rancati, 2017; Wang et al., 2019). In particular, women may reduce the coordination and communication problems in the boardroom that increase the effectiveness of board decision-making enhancing firm value (Joecks et al., 2013); whereas the intense monitoring of female executives would be the casual effect to reduce firm performance (Eagly, 2007; Adams \& Ferreira, 2009; Adams et al., 2015). Moreover, several studies do not show any significant relation between having female leaders and a firm's performance (Kochan et al., 2003; Marinova et al., 2016). However, relevant studies are mostly restricted in a specific market (Gordini \& Rancati, 2017), and very few regarded research in the financial sector (Reinert et al., 2016). Therefore, it might not provide adequate empirical evidence for female leadership in the financial sector, which is seriously controlled by very tight governance mechanisms, especially during the economic recovery period such as Western European (WE) market. Thus, we state the necessity to fulfill the empirical evidence of female leadership's role in the context of WE region, but not in a specific market. This study is also more valuable since it is posited in the financial sector, which is still greatly dominated by men.

Consequently, by using the unique dataset of financial companies listed on the WE equity market from 2014 to 2017, we aim to shed light on the role of female leadership on the firm's performance and review the economic recovery period in-depth. Thus, our study provides several vital contributions. First, this study is one of the few regarded studies arguing a negative relationship between female leadership and performance of a firm in financial sector, which is consistent with the findings in Adams and Ferreira (2009), further denning the benefits of adding more women into the board of directors (Joecks et al., 2013). Second, by considering the context of the WE market, we support that the negative relationship between female leadership and firm performance might be caused by the negative consequences of the recent financial crisis (Tucaa, 2014). In line with that view, the constrained corporate governance mechanism may restrict the executives in deciding a new credit that reduces firm's accounting-based performance (Avgouleas \& Cullen, 2014). More particularly, female directors with unique characteristics may monitor more and are more conservative than their male counterparts in their investment related decisions, causing a decrease in the firm performance. Finally, our sample consists of $21 \mathrm{WE}$ countries, therefore the policymakers may consider its empirical results to reduce the appearance of women in the boardroom to balance the firm's strategy. We argue that gender diversity will benefits firms depending on the specific context and industries. 


\section{LITERATURE REVIEW}

Corporate governance is the process by which the management entity impacts the management objects to perform and coordinate individual, collective, functional parts, and more, to realize the collective and the enterprise (Berle \& Means, 1932). The relevant literature mentioned that firms with good governance are assumed to provide transparent disclosure of decision-allocation and positively affect firm performance (Ammann et al., 2011). Within the corporate governance studies, board composition plays a vital role in the internal governance mechanisms (Abatecola, 2014), because it influences the effectiveness of boards' roles and functions which impact the firm's performance (De Andres \& Vallelado, 2008). Research has investigated the effect of board composition on firm performance in terms of - board size and independent non-executive (Peni \& Vähämaa, 2012), the share ownership of board members (Hermalin \& Weisbach, 1988), and remuneration scheme used (Rose, 2007). However, the relationship between board's diversity and firm's performance has been much more attractive in the academic field (Masulis et al., 2012). Board diversity is the variety inherent in a board's composition, which alludes to the number of female executives on the board (Gordini \& Rancati, 2017). Although the research on board's gender diversity and firm performance is growing rapidly, the findings are inconclusive (Zhang et al., 2016). Thus, the association between women at alternative managerial levels and firm performance will be discussed in the next following section.

\subsection{The linkage between women's leadership and firm performance}

It is unclear whether a female chairperson (or so-called chairwoman) plays a more effective leadership role than male counterparts, and there are very few regarded studies on the impact of a chairwoman on firm value. Barney (1991) regarded a women's role as an internal resource that can be capitalized as a competitive advantage for a firm. Shrader et al. (1997) also adopted that view. Given that male and females tend to differ in several respects, Hillman et al. (2002) indicate that women have unique characteristics different from male counterparts on experiences and work styles to be efficient leaders. Indeed, it is also mentioned that women are the critical components of a firm's resources. Thus, their appearance in the workplace delivers unique values such as effective coordination and better communication in a boardroom, and hence leading to improve the firm's decision-making which is essential to increase the firm performance (Hillman et al., 2007; Peterson \& Philpot, 2007).

Conversely, several studies present the negative effects on the firm performance with a chairwoman. Eagly and Karau (2002) propose that gender stereotyping of women, by investors is the primary reason to reduce their achievements in leadership roles. It implies that firms a higher women proportion may negatively impact a firm's performance, especially in the sectors which are male dominated (Fairlie \& Robb, 2009). Singhathep and Pholphirul (2015) found that female executive leaders may hurt the firm's financial performance, including annual revenue and profit. Interestingly, although women are mentioned to engage with successful business organizations, female leaders would negatively affect the firm's performance (Eagly, 2007). Besides, Bennouri et al. (2018) show substantial shreds of evidence that female leaderships' significant influence on firm performance will depend on their attributes. In particular, higher female director increases accounting-based performance, but it decreases market-based performance. 
Given the inconsistency of prior studies' results, the issue of female leadership and its association with firm financial performance undoubtedly requires further investigation. Accordingly, extending the existing literature, we argue that the chairwoman would negatively impact WE financial firm performance. Thus, we propose two first hypotheses as follows:

H1a: Chairwoman has a significant negative impact on accounting-based performance Hla: Chairwoman has a significant negative impact on market-based performance

\subsection{The relation between female executive directors and firm performance}

Gender equality and women empowerment are mentioned to play a key role in enriching corporate governance research. In this study, we discuss the number of female executive committees in the boardroom. In particular, it is suggested that female executive directors' involvement is increasingly recognized as the critical factor that may determine firm performance and success of organizations (Terjesen et al., 2015; Tate \& Yang, 2015). Despite the growing studies of the relationship between female executive directors and firm performance, empirical evidence is decidedly mixed. Erhardt et al. (2003) find that the increase in the number of women in executive positions associates with better performance. Furthermore, Nguyen et al. (2015) present that a female executive leadership, also, significantly impacts firm performance even in the transitional economy, where the concept of corporate governance was in its early stage.

However, the relevant literature also addresses the negative impact of firm performance if women hold executive positions (Amran, 2011; Hsu et al., 2013). In particular, Adams and Ferreira (2009) states that the participation of women in executive boards could lead to a significant negative correlation with firm performance. Zhang et al. (2016) indicate that female executive leader may weaken the firm performance by their unique characteristics. For example, women executive directors are too conservative and restricted monitoring on boards. Therefore, they enhance conflicts in decision-making that delay firm's strategy implementation or lose advantage due to missing investment opportunities (Adams \& Ferreira, 2009).

Regarding the viewpoint that the proportion of female executive directors could lead to an increase in restricted monitoring in the boardroom affecting the firm's strategies and growth opportunities in financial institutions, especially during the economic recovery. We, therefore, propose the next hypotheses as follows:

H2a: The female executive director has a significant negative impact on accounting-based performance

$H 2 b$ : The female executive director has a significant negative impact on market-based performance

\subsection{Gender diversity in the boardroom and firm performance}

Gender diversity is defined as the total number of women in the boardroom (including female executive and non-executive directors) (Zhang et al., 2016). In particular, Carter et al. (2003) present the significant positive relationship between market-based performance and the proportion of women on boards in the American market. Later, Bonn (2004) employs a large sample of 
Australian listed companies and found that a higher female proportion attending in boards could improve firm performance, described by return on equity and market-to-book value ratios. Mukarram et al. (2018) propose that leadership style is dissimilar across genders and indicate that female board member performs better than their male counterparts on market performance. Besides, Li and Chen (2018) show that the firm's size could explain the positive influences of gender diversity in the board and firm performance in terms of whether the firm value is less than a threshold value. In another context, such as the inadequate governance mechanisms market, the firms may gain more value by increasing gender diversity in the boardroom (Ionascu et al., 2018). On the other hand, Tran et al. (2020) indicate that the presence of women directors could help the firm reduce risk-taking behavior.

On the contrary, several studies provide evidence that the appearance of female directors would lead to worse performance. Adams and Ferreira (2009) point out the negative relation between female participation on boards and firm profitability due to their over-monitoring characteristic in the boardroom. Also, Kochan et al. (2003) explain that the more appearance of women on boards increases the cost of decision making and the possibility of conflict in the executive team, which may weaken firm performance. Joecks et al. (2013) shows that firm performance may be decreased if boards reach more than 30 percent of female directors.

From the viewpoint that gender diversity might increase the cost of decision-making and overmonitoring in the boardroom, which may weaken firm financial performance (Kochan et al., 2003), especially in the financial sector. We then propose the negative association between the proportion of female directors and firm performance that leads to the next hypotheses as follows:

\section{H3a: The proportion of female directors has a significant negative impact on accounting-based performance \\ $H 3 b$ : The proportion of female directors has a significant negative impact on market-based performance}

Table 1. Overview of the literature on the impact of female leadership on firm performance

\begin{tabular}{|c|c|c|}
\hline Study & Impact & Findings \\
\hline \multicolumn{3}{|c|}{ The linkage between female leadership and firm performance } \\
\hline $\begin{array}{l}\text { Hillman et al. (2007); } \\
\text { Peterson \& Philpot } \\
\text { (2007) }\end{array}$ & Positive & $\begin{array}{l}\text { The presence of female directors on boards has a positive } \\
\text { corporate firm's image and enhances firm performance. }\end{array}$ \\
\hline $\begin{array}{l}\text { Barney (1991), Shrader et } \\
\text { al. (1997) }\end{array}$ & Positive & $\begin{array}{l}\text { They considered that the role of women can be seen as the firm's } \\
\text { competitive advantage. }\end{array}$ \\
\hline Bennouri et al. (2018) & Positive & $\begin{array}{l}\text { Female CEO or chairperson make a positive impact on } \\
\text { accounting-based performance but negatively affects the market- } \\
\text { based outcome. }\end{array}$ \\
\hline Eagly \& Karau (2002) & Negative & $\begin{array}{l}\text { the relationship between women directors and market-based } \\
\text { measures of firm performance is considered negative. }\end{array}$ \\
\hline $\begin{array}{l}\text { Eagly (2009); Singhathep } \\
\text { \& Pholphirul (2015) }\end{array}$ & Negative & Female leaders may decrease annual revenue and profit. \\
\hline Fairlie \& Robb (2009) & Negative & $\begin{array}{l}\text { Women-run businesses are considered less successful in terms of } \\
\text { financial performance. }\end{array}$ \\
\hline
\end{tabular}




\begin{tabular}{|c|c|c|}
\hline $\begin{array}{l}\text { Terjesen et al. (2015); } \\
\text { Tate \& Yang (2015) }\end{array}$ & Positive & $\begin{array}{l}\text { The high involvement of female executive directors determines } \\
\text { the firm performance }\end{array}$ \\
\hline Erhardt et al. (2003) & Positive & $\begin{array}{l}\text { The female executive director is positively associated with firm } \\
\text { performance }\end{array}$ \\
\hline Nguyen et al. (2015) & Positive & $\begin{array}{l}\text { The female executive leadership positively affects firm } \\
\text { performance even in the emerging market with a poor } \\
\text { governance environment. }\end{array}$ \\
\hline $\begin{array}{l}\text { Amran (2011); Hsu et al. } \\
\text { (2013) }\end{array}$ & Negative & $\begin{array}{l}\text { The study concluded that women executives have a negative } \\
\text { impact on the firm's performance. }\end{array}$ \\
\hline Adams \& Ferreira (2009) & Negative & $\begin{array}{l}\text { Companies with fewer takeover defenses drive the negative } \\
\text { relationship between female executive directors and firm } \\
\text { performance. }\end{array}$ \\
\hline Zhang et al. (2016) & Negative & $\begin{array}{l}\text { Female executive leaders are too conservative and may enhance } \\
\text { the conflicts on board. Therefore, firm performance may be } \\
\text { weakened. }\end{array}$ \\
\hline \multicolumn{3}{|c|}{ Gender diversity in the boardroom and firm performance } \\
\hline Carter et al. (2003) & Positive & $\begin{array}{l}\text { The research present that there is a positive relationship between } \\
\text { the woman on boards and market-based performance. }\end{array}$ \\
\hline Bonn (2004) & Positive & $\begin{array}{l}\text { The research showed that woman on board improves firm } \\
\text { performance in terms of ROE and market-to-book value ratio. }\end{array}$ \\
\hline Mukarram et al. (2018) & Positive & $\begin{array}{l}\text { The research proposed that female leaders perform better than } \\
\text { their counterparts on market-based performance. }\end{array}$ \\
\hline Li \& Chen (2018) & Positive & $\begin{array}{l}\text { Firm size may explain the relationship between gender diversity } \\
\text { in the boardroom and the performance of companies. }\end{array}$ \\
\hline Ionascu et al. (2018) & Positive & $\begin{array}{l}\text { High gender diversity in the boardroom increases firm } \\
\text { performance even in less developed markets. }\end{array}$ \\
\hline Kochan et al. (2003) & Negative & $\begin{array}{l}\text { The involvement of women on boards increases cost-decision } \\
\text { making that may weaken firm performance. }\end{array}$ \\
\hline Joecks et al. (2013) & Negative & $\begin{array}{l}\text { In case the number of women on board reaches } 30 \text { percent, } \\
\text { gender diversity will negatively impact the firm performance. }\end{array}$ \\
\hline Adams \& Ferreira (2009) & Negative & $\begin{array}{l}\text { The negative relation between female participation on boards } \\
\text { and firm profitability because of their over-monitoring director's } \\
\text { role. }\end{array}$ \\
\hline
\end{tabular}

\section{METHODOLOGY}

\subsection{Data}

This paper employs a unique sample consistent with 310 listed financial institutions from 21 Western European equity markets in the 2014-2017 period (including 4,960 year-observations). The data was gathered from Osiris, that is mentioned as, one of the most comprehensive databases and is frequently used by scholars in theoretical model testing (Nanka-Bruce, 2011). Furthermore, the 2014-2017 period was selected due to several reasons. First, that horizon is marked as Europe's economic recovery after facing to financial crisis since 2008 (Tucaa, 2014). Corporate governance mechanisms are mentioned as the critical role embedded in European's economic recovery planning, especially in the financial sector (Amorello \& Huber, 2014). Second, although the European Commission requires quotas for women on corporate boards of European companies, the proportion of women in managerial levels even in the labor force was still low (Isidro \& Sobral, 
2015). Therefore, the relationship between female leadership and firm performance should be analyzed in the period from 2014 to 2017.

\subsection{Variables}

This study uses two key ratios to describe market-based (Tobin's Q) and accounting-based (Return on assets-ROA) performance. In particular, Tobin's $Q$ is defined as the sum of the stock's market value and the book value of debt divided by the book value of total assets (Gordini \& Rancati, 2017). Besides, we select ROA because it is the key factor to benchmark for financial organizations' profitability since it measures the company's return on investment that is easily compared with other institutions (Caprio et al., 2007). In addition, Tobin's Q was selected because it reflected the market's expectations of future earning (Wernerfelt \& Montgomery, 1988). Furthermore, while ROA shows the past performance, Tobin's Q focuses on future performance and could explain future risks (Gordini \& Rancati, 2017).

Furthermore, to explore the relationship between female leadership and firm performance, we use three variables to measure female leadership. The first is a dummy variable, Fc, which is equal to 1 when the chairperson is a woman (or so-called chairwoman) and 0 otherwise. The second is the percentage of female executive directors, $\mathrm{Fe}$, in the boardroom. These two variables alone are not the appropriate measures of gender diversity. Thus, we further calculate the third variable, which is the proportion of total women in the boardroom $(\mathrm{Fb})$.

Finally, in line with previous research (Campbell \& Mínguez-Vera, 2008; Vafaei, Ahmed, \& Mather, 2015; Gordini \& Rancati, 2017; Tran et al., 2020), we use a set of control variables which are listed in table 2 to control for the proposed econometric model.

\subsection{Econometric model}

This study applies the three-stage analysis to validate the regression results. In the first step, the influence of female leaders towards firm performance is estimated by ordinary least square (OLS), that is widely used in board composition contexts (Ionascu et al., 2018). However, Carter et al. (2010) acknowledge that OLS is inefficient or consistent to deal with the endogenous concern. Therefore, in the second step, we apply the Two-stage least squares (2SLS) regression, as it corrects the potential endogeneity problems (Gordini \& Rancati, 2017). Following Poletti-Hughes and Briano-Turrent (2019), this study employs the logarithm of firm age (Age), and the proportion of female directors in a firm to all firms (Fes) are two instrumental variables for ownership (Cap). We test and confirm that ownership is truly endogenous by Hausman (1978) test. Then, we test for overidentifying restrictions to check for instrument exogeneity with the Sargan-test, indicating that the instrument may not be valid. The outcomes from these tests indicate the validity of two selected instrumental variables. Finally, to further validate our results, we apply the Generalized method of moments (GMM), which is also mentioned to deal with potential endogeneity concerns, omitted variable bias (Wintoki et al., 2012). The study's hypotheses are tested by running the following econometric model:

$$
\text { Performance }_{i, t}=\beta_{0}+\sum \beta_{j} \text { FLeader }_{j, i, t}+\sum \beta_{j} \text { Firm }_{j, i, t}+\Phi_{t}+\Psi_{i}+\varepsilon_{i, t}
$$


Where Performance denotes firm's accounting (ROA) and market-based (Tobin's Q) performance, FLeader denotes three alternative variables used to measure the role of female leadership, Firm denotes the firm's characteristics as control variables, $\Phi$ refers to time effects, and $\Psi$ refers to the unobservable heterogeneit.

Table 2. Variables descriptions

\begin{tabular}{|c|c|c|}
\hline Variables & Meaning & Description \\
\hline \multicolumn{3}{|l|}{ Female leadership } \\
\hline $\begin{array}{l}\text { Gender of chairperson (so- } \\
\text { called chairwoman) }\end{array}$ & $\mathrm{Fc}$ & $\begin{array}{l}\text { Dummy variable which is equal } 1 \text { if the firm's } \\
\text { chairperson is female and } 0 \text { otherwise }\end{array}$ \\
\hline Female executive directors & $\mathrm{Fe}$ & $\begin{array}{l}\text { The proportion of female executive directors in the } \\
\text { boardroom. }\end{array}$ \\
\hline $\begin{array}{l}\text { Female non-executive } \\
\text { directors }\end{array}$ & Fne & $\begin{array}{l}\text { The proportion of female non-executive directors in the } \\
\text { boardroom. }\end{array}$ \\
\hline Female directors & $\mathrm{Fb}$ & $\begin{array}{l}\text { The proportion of total female directors in the } \\
\text { boardroom. }\end{array}$ \\
\hline \multicolumn{3}{|l|}{ Firm financial performance } \\
\hline $\begin{array}{l}\text { Accounting-based } \\
\text { performance }\end{array}$ & $\begin{array}{l}\text { Return on } \\
\text { assets } \\
\text { (ROA) }\end{array}$ & The ratio of net income to total assets \\
\hline Market-based performance & Tobin's Q & $\begin{array}{l}\text { The ratio of the market value of a company divided by } \\
\text { its assets' replacement cost }\end{array}$ \\
\hline \multicolumn{3}{|l|}{ Control variables } \\
\hline Total of executive directors & Exe & Total number of executive directors in the firm \\
\hline Total of managers & Ма & Total number of managers in the firm \\
\hline Firm's leverage & $\mathrm{Fa}$ & The ratio of total assets to total equity \\
\hline Firm size & Size & The natural logarithm of total assets \\
\hline Revenue capita & $\mathrm{Be}$ & The natural logarithm of net income \\
\hline Firm market capitalization & Market & The natural logarithm of market capability \\
\hline $\begin{array}{l}\text { The volatility of the market's } \\
\text { stock }\end{array}$ & Risk & $\begin{array}{l}\text { Beta ratio which is estimated from Capital asset pricing } \\
\text { model (CAPM) model }\end{array}$ \\
\hline Ownership & Cap & The ratio of shareholder equity to total assets \\
\hline $\begin{array}{l}\text { Female empowerment in the } \\
\text { boardroom }\end{array}$ & Fes & The ratio of female directors in a firm to all firms. \\
\hline Firm age & Age & $\begin{array}{l}\text { The natural logarithm of firm age from the founded year } \\
\text { until } 2017\end{array}$ \\
\hline
\end{tabular}

\section{EMPIRICAL RESULTS}

\subsection{Descriptive data}

Table 3 shows the statistics for all variables. In particular, the mean of Tobin's Q ratio is lower than 1 (0.366), and ROA is 2.52. Although most firms can create profit in the observed period, the markets or investors are very conservative on the firm's future growth opportunities. Among independent variables, the mean of chairwoman and female executive directors are relatively small, with approximately 9 and 13.6 percent, respectively. In contrast, the ratio of female directors 
is high with approximately 21 percent. These numbers indicate that a very low proportion of women who can impact the firm's strategy decisions despite their high significant presence in the boardroom. Furthermore, the mean of market capitalization is high (12.805), and beta is 0.684 (under 1) confirm the conservative of investors in investing to firm lower-risk securities.

Table 3. Descriptive Statistics

\begin{tabular}{|c|c|c|c|c|c|}
\hline Variables & Observations & Mean & $\begin{array}{l}\text { Standard } \\
\text { Deviation }\end{array}$ & Min & Max \\
\hline ROA & 1,240 & 2.520 & 6.662 & -22.031 & 66.490 \\
\hline Tobin's Q & 1,240 & 0.366 & 0.673 & 0.000 & 10.123 \\
\hline $\mathrm{Fc}$ & 1,240 & 0.090 & 0.287 & 0.000 & 1.000 \\
\hline $\mathrm{Fe}$ & 1,240 & 0.136 & 0.157 & 0.000 & 1.000 \\
\hline Fne & 1,240 & 0.072 & 0.101 & 0.000 & 0.500 \\
\hline $\mathrm{Fb}$ & 1,240 & 0.208 & 0.158 & 0.000 & 1.000 \\
\hline $\mathrm{Fm}$ & 1,240 & 2.742 & 3.798 & 0.000 & 18.000 \\
\hline Exe & 1,240 & 0.634 & 0.326 & 0.000 & 1.000 \\
\hline $\mathrm{Ma}$ & 1,240 & 13.713 & 14.912 & 0.000 & 50.000 \\
\hline $\mathrm{Fa}$ & 1,240 & 9.122 & 7.392 & 0.262 & 57.928 \\
\hline Size & 1,240 & 14.882 & 2.834 & 7.355 & 21.649 \\
\hline $\mathrm{Be}$ & 1,240 & 9.260 & 4.250 & 0.000 & 17.472 \\
\hline Market & 1,240 & 12.805 & 2.312 & 1.533 & 20.126 \\
\hline Risk & 1,240 & 0.684 & 1.732 & -0.710 & 29.570 \\
\hline Cap & 1,240 & 0.291 & 0.316 & 0.004 & 1.000 \\
\hline Age & 1,240 & 3.807 & 1.035 & 0.000 & 6.301 \\
\hline Fes & 1,240 & 0.001 & 0.001 & 0.000 & 0.006 \\
\hline
\end{tabular}

\subsection{Ordinary least square regression}

Table 4 presents the OLS regression outcomes for the relationship between female leadership and firm performance. The results indicate that chairwoman has a negative influence on ROA (column 4), confirming $\boldsymbol{H} \boldsymbol{1 b}$, whereas no-significance was found with Tobin's Q (column 1) that does not support H1a. Then, we distinguish the measure for female executive and non-executive directors and find evidence that the higher female executive directors significantly lower both two estimators of firm performance (columns 2 and 5). These outcomes support $\boldsymbol{H} 2 \boldsymbol{a}$ and $\boldsymbol{H} \boldsymbol{2} \boldsymbol{b}$. Besides, the regressions further present that female non-executive director has a positive significance with Tobin's Q (column 5) indicating the high assessment of the market on the participation of women in non-executive functions such as the supervisor or audit members. It is because female nonexecutive directors are emphasized to increase firm benefits in scrutinizing executive director's performance, reducing information asymmetries, and dysfunctional working relation to protect shareholder's value rather than involvement to firm' strategy planning (Peij et al., 2012).

Consequently, for the listed financial firms in the WE region, the chairwoman and executive directors negatively affect the market participants' subjective perspective. Although many studies show the positive effect that female executives cause to enhance firm value (Hillman et al., 2007; Gordini \& Rancati, 2017). However, the negative correlation between female executive directors and market-based performance could be explained by market participants' concerns of the overmonitoring and intervention behaviors derived from female executive directors and chairwoman 
that may reduce firm's growth opportunities (Adams \& Ferreira, 2009). Besides, the negative relationship between chairwoman and market-based performance may be driven by the trade-off between costs and benefits of diversity on board effectiveness (Bennouri et al., 2018).

We further investigate whether the impact of the presence of women on board is different for the firm performance. We find that the proportion of female directors has a negative effect on accounting-based performance. Thus, that result rejects $\boldsymbol{H 3} \boldsymbol{b}$, but supports $\boldsymbol{H} \mathbf{3} \boldsymbol{a}$. These results indicate that the appearance of female directors in the boardroom might restrict the firm's benefits that are consistent with the investment efficiency of WE financial institutions. Besides, the negative relationship between female directors and accounting performance might be driven by the constrained regimes to safeguard financial stability after the crisis (Avgouleas \& Cullen, 2014).

Table 4. OLS regressions for firm performance and female leadership.

\begin{tabular}{|c|c|c|c|c|c|c|}
\hline \multirow{2}{*}{ OLS } & \multicolumn{3}{|l|}{ ROA } & \multicolumn{3}{|c|}{ obin's Q } \\
\hline & (1) & (2) & (3) & (4) & (5) & (6) \\
\hline \multirow[t]{2}{*}{$\mathrm{Fc}$} & 0.002 & & & $-0.092 *$ & & \\
\hline & (0.998) & & & (0.089) & & \\
\hline \multirow[t]{2}{*}{$\mathrm{Fe}$} & & $-3.592 * * *$ & & & $-0.229 * *$ & \\
\hline & & $(0.000)$ & & & $(0.031)$ & \\
\hline \multirow[t]{2}{*}{ Fne } & & -1.946 & & & $0.449 * * *$ & \\
\hline & & $(0.234)$ & & & $(0.008)$ & \\
\hline \multirow[t]{2}{*}{$\mathrm{Fb}$} & & & $-3.495 * * *$ & & & -0.062 \\
\hline & & & $(0.001)$ & & & $(0.565)$ \\
\hline \multirow[t]{2}{*}{$\mathrm{Fm}$} & & & 0.071 & & & -0.003 \\
\hline & & & $(0.380)$ & & & (0.691) \\
\hline \multirow[t]{2}{*}{ Exe } & -0.951 & & -0.829 & -0.152 & & -0.147 \\
\hline & $(0.051)$ & & $(0.088)$ & $(0.003)$ & & $(0.004)$ \\
\hline \multirow[t]{2}{*}{ MA } & -0.005 & -0.003 & -0.021 & 0.002 & 0.001 & 0.002 \\
\hline & $(0.658)$ & $(0.790)$ & $(0.317)$ & $(0.185)$ & $(0.223)$ & $(0.295)$ \\
\hline \multirow[t]{2}{*}{$\mathrm{Fa}$} & 0.011 & 0.017 & 0.011 & 0.001 & 0.001 & 0.001 \\
\hline & $(0.724)$ & $(0.574)$ & (0.718) & $(0.825)$ & (0.789) & $(0.78)$ \\
\hline \multirow[t]{2}{*}{ Size } & -0.657 & -0.618 & -0.609 & -0.058 & -0.059 & -0.059 \\
\hline & $(0.000)$ & $(0.000)$ & $(0.000)$ & $(0.000)$ & $(0.000)$ & $(0.000)$ \\
\hline \multirow[t]{2}{*}{$\mathrm{Be}$} & 0.849 & 0.843 & 0.844 & 0.016 & 0.017 & 0.017 \\
\hline & $(0.000)$ & $(0.000)$ & $(0.000)$ & $(0.000)$ & $(0.000)$ & $(0.000)$ \\
\hline \multirow[t]{2}{*}{ Market } & 0.125 & 0.125 & 0.121 & 0.0034 & 0.001 & 0.004 \\
\hline & $(0.156)$ & $(0.158)$ & (0.171) & $(0.703)$ & (0.938) & $(0.650)$ \\
\hline \multirow[t]{2}{*}{ Risk } & 8.117 & 8.204 & 8.092 & 0.936 & 0.927 & 0.927 \\
\hline & $(0.000)$ & $(0.000)$ & $(0.000)$ & $(0.000)$ & $(0.000)$ & $(0.000)$ \\
\hline \multirow[t]{2}{*}{ Cap } & 0.028 & 0.100 & 0.096 & -0.053 & -0.052 & -0.052 \\
\hline & $(0.853)$ & $(0.518)$ & $(0.531)$ & $(0.001)$ & $(0.001)$ & $(0.001)$ \\
\hline \multirow{2}{*}{ Cons } & 2.460 & 1.570 & 2.224 & 1.081 & 0.981 & 1.093 \\
\hline & $(0.066)$ & $(0.210)$ & $(0.096)$ & $(0.000)$ & $(0.000)$ & $(0.000)$ \\
\hline Obs & 1,240 & 1,240 & 1,240 & 1,240 & 1,240 & 1,240 \\
\hline R2 & 0.388 & 0.392 & 0.393 & 0.362 & 0.365 & 0.361 \\
\hline
\end{tabular}

Notes: We report the regression estimations from the following equation (1). All variables are defined in Table 1. P-values of coefficient significance are in brackets. Statistically significant at $1 \%(* * *), 5 \%(* *)$ and $10 \%(*)$. 


\section{$4.32 S L S$ regression}

As discussed above, we then apply 2SLS to remove endogeneity concerns and validate OLS regression results. Table 5 shows that the results are obtained in the 2SLS, which confirm our hypotheses including the negative relationship between chairwoman and market-based performance; the negative correlation between female executive directors, the total number of female directors, and accounting-based performance are remained. These outcomes validate $\boldsymbol{H} \mathbf{2 a}$ which is confirmed by Fischer et al. (1993) and Adams and Ferreira (2009), whereas $\boldsymbol{H} \boldsymbol{1 b}$ is consistent with Bennouri et al. (2018). The significance of $\boldsymbol{H 3} \boldsymbol{a}$ is consistent with Avgouleas and Cullen (2014). However, the correlation between female non-executive directors and market-based performance is no longer significant or even positive.

Regarding the controls, we find a positive correlation between firm market size (Market) and two measurements of firm performance is consistent with Vafaei et al. (2015). However, the negative impact of firm size (Size) on firm performance implies the inefficiency of investment to create profit and lower growth opportunities of larger firms than the others (Hasan et al., 2014). Besides, the relationship between risk and firm performance no longer remains. Furthermore, Tobin's Q is positively correlated with firm ownership, indicating that a firm with higher ownership enhances firm value according to the entrenchment effect (Villalonga \& Amit, 2006).

Furthermore, to confirm the validity of model regressions and deal with endogeneity concerns, Sagan and Wu-Hausman tests are applied after running 2SLS regressions. The final results show the validity of all models and the goodness-of-fit of two instrumental variables.

Table 5. 2SLS Regressions for firm performance and female leadership

\begin{tabular}{|c|c|c|c|c|c|c|}
\hline \multirow{2}{*}{ 2SLS } & \multicolumn{3}{|l|}{ 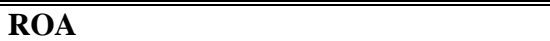 } & \multicolumn{3}{|c|}{ Cobin's Q } \\
\hline & (1) & (2) & (3) & (4) & (5) & (6) \\
\hline \multirow{2}{*}{$\mathrm{Fc}$} & 0.354 & & & $0.160 * * *$ & & \\
\hline & $(0.555)$ & & & $(0.008)$ & & \\
\hline \multirow{2}{*}{$\mathrm{Fe}$} & & $-3.112 * * *$ & & & 0.009 & \\
\hline & & $(0.005)$ & & & $(0.934)$ & \\
\hline \multirow{2}{*}{ Fne } & & -0.450 & & & 0.174 & \\
\hline & & $(0.808)$ & & & $(0.348)$ & \\
\hline \multirow{2}{*}{$\mathrm{Fb}$} & & & $-2.768 * *$ & & & 0.034 \\
\hline & & & $(0.014)$ & & & $(0.763)$ \\
\hline \multirow{2}{*}{$\mathrm{Fm}$} & & & 0.073 & & & 0.0023 \\
\hline & & & $(0.395)$ & & & (0.792) \\
\hline \multirow{2}{*}{ Exe } & -1.944 & & -0.0355 & 0.033 & & 0.000 \\
\hline & $(0.004)$ & & $(0.128)$ & $(0.624)$ & & $(0.839)$ \\
\hline \multirow{2}{*}{ MA } & -0.024 & -0.015 & -1.581 & 0.001 & 0.001 & 0.017 \\
\hline & $(0.097)$ & $(0.275)$ & $(0.013)$ & $(0.360)$ & $(0.602)$ & (0.789) \\
\hline \multirow{2}{*}{$\mathrm{Fa}$} & -0.236 & -0.171 & -0.1672 & 0.0342 & 0.029 & 0.029 \\
\hline & $(0.02)$ & $(0.081)$ & $(0.08)$ & $(0.001)$ & $(0.003)$ & $(0.002)$ \\
\hline \multirow{2}{*}{ Size } & -2.167 & -1.807 & -1.722 & -0.084 & -0.108 & -0.113 \\
\hline & (0.000) & $(0.000)$ & (0.000) & (0.105) & $(0.036)$ & $(0.021)$ \\
\hline \multirow{2}{*}{$\mathrm{Be}$} & 0.830 & 0.825 & 0.829 & 0.005 & 0.0061 & 0.006 \\
\hline & (0.000) & $(0.000)$ & $(0.000)$ & (0.333) & $(0.183)$ & $(0.220)$ \\
\hline Market & 1.421 & 1.125 & 1.057 & 0.088 & 0.106 & 0.112 \\
\hline
\end{tabular}




\begin{tabular}{lrrrrrr} 
& $(0.002)$ & $(0.015)$ & $(0.016)$ & $(0.055)$ & $(0.022)$ & $(0.011)$ \\
Risk & 0.130 & 0.129 & 0.121 & -0.000 & -0.001 & 0.001 \\
& $(0.185)$ & $(0.173)$ & $(0.192)$ & $(0.999)$ & $(0.946)$ & $(0.952)$ \\
Cap & -6.715 & -3.3054 & -2.653 & 2.132 & 1.868 & 1.832 \\
& $(0.220)$ & $(0.537)$ & $(0.604)$ & $(0.000)$ & $(0.000)$ & $(0.000)$ \\
Cons & 14.446 & 10.456 & 11.023 & -0.517 & -0.273 & -0.260 \\
Obs & $(0.002)$ & $(0.016)$ & $(0.013)$ & $(0.277)$ & $(0.530)$ & $(0.562)$ \\
R2 & 1,240 & 1,240 & 1,240 & 1,240 & 1,240 & 1,240 \\
W-Chi 2 & 0.235 & 0.299 & 0.315 & 0.250 & 0.312 & 0.319 \\
Sargan & 0.000 & 0.000 & 0.000 & 0.000 & 0.000 & 0.000 \\
Endogenous & 0.278 & 0.745 & 0.728 & 0.830 & 0.459 & 0.514 \\
\hline \hline
\end{tabular}

\subsection{GMM regression}

In table 6, we apply GMM to validate and corroborate our previous findings. Overall, the signs of the coefficient of 2SLS and GMM regressions are the same. In confirming $\boldsymbol{H 2 a}$, the results indicate that the significant decrease in accounting-based performance is driven by female executive directors (albeit not significantly for female non-executive directors). To confirm $\boldsymbol{H} \mathbf{1 b}$, the negative relationship between chairwoman and market-based performance still remains. Besides, firm accounting-based performance is decreased by the increase in the proportion of female directors which confirms $\boldsymbol{H 3} \boldsymbol{a}$. Finally, we run the Hansen test of over-identification is under the null instruments are validity.

Table 6. GMM Regressions for firm performance and female leadership

\begin{tabular}{|c|c|c|c|c|c|c|}
\hline \multirow{2}{*}{ GMM } & \multirow[t]{2}{*}{ ROA } & \multicolumn{5}{|c|}{ Tobin's Q } \\
\hline & & (2) & (3) & (4) & (5) & (6) \\
\hline $\mathrm{Fc}$ & $\begin{array}{r}0.440 \\
(0.504)\end{array}$ & & & $\begin{array}{r}0.160 * * * * \\
(0.000)\end{array}$ & & \\
\hline $\mathrm{Fe}$ & & $\begin{array}{r}-3.191 * * * * \\
(0.000)\end{array}$ & & & $\begin{array}{r}0.007 \\
(0.923)\end{array}$ & \\
\hline Fne & & $\begin{array}{r}-0.633 \\
(0.743)\end{array}$ & & & $\begin{array}{r}0.158 \\
(0.417)\end{array}$ & \\
\hline $\mathrm{Fb}$ & & & $\begin{array}{r}-2.859 * * * * \\
(0.002)\end{array}$ & & & $\begin{array}{r}0.022 \\
(0.824)\end{array}$ \\
\hline $\mathrm{Fm}$ & & & $\begin{array}{r}0.070 \\
(0.251)\end{array}$ & & & $\begin{array}{r}0.004 \\
(0.468)\end{array}$ \\
\hline Exe & $\begin{array}{r}-1.986 \\
(0.001)\end{array}$ & & $\begin{array}{r}-0.034 \\
(0.063)\end{array}$ & $\begin{array}{r}0.033 \\
(0.557)\end{array}$ & & $\begin{array}{r}0.000 \\
(0.983)\end{array}$ \\
\hline MA & $\begin{array}{r}-0.023 \\
(0.054)\end{array}$ & $\begin{array}{r}-0.014 \\
(0.189)\end{array}$ & $\begin{array}{r}-1.589 \\
(0.004)\end{array}$ & $\begin{array}{r}0.001 \\
(0.079)\end{array}$ & $\begin{array}{r}0.001 \\
(0.347)\end{array}$ & $\begin{array}{r}0.024 \\
(0.674)\end{array}$ \\
\hline $\mathrm{Fa}$ & $\begin{array}{r}-0.243 \\
(0.001)\end{array}$ & $\begin{array}{r}-0.170 \\
(0.009)\end{array}$ & $\begin{array}{r}-0.167 \\
(0.008)\end{array}$ & $\begin{array}{r}0.034 \\
(0.000)\end{array}$ & $\begin{array}{r}0.029 \\
(0.000)\end{array}$ & $\begin{array}{r}0.028 \\
(0.000)\end{array}$ \\
\hline Size & $\begin{array}{r}-2.283 \\
(0.000)\end{array}$ & $\begin{array}{r}-1.832 \\
(0.000)\end{array}$ & $\begin{array}{r}-1.748 \\
(0.000)\end{array}$ & $\begin{array}{r}-0.09 \\
(0.023)\end{array}$ & $\begin{array}{c}-0.1233 \\
(0.000)\end{array}$ & $\begin{array}{l}-0.127 \\
(0.000)\end{array}$ \\
\hline $\mathrm{Be}$ & $\begin{array}{r}0.828 \\
(0.000)\end{array}$ & $\begin{array}{r}0.828 \\
(0.000)\end{array}$ & $\begin{array}{r}0.832 \\
(0.000)\end{array}$ & $\begin{array}{r}0.004 \\
(0.338)\end{array}$ & $\begin{array}{r}0.006 \\
(0.171)\end{array}$ & $\begin{array}{r}0.005 \\
(0.232)\end{array}$ \\
\hline
\end{tabular}




\begin{tabular}{lrrrrrr} 
Market & 1.487 & 1.129 & 1.059 & 0.092 & 0.120 & 0.125 \\
& $(0.000)$ & $(0.000)$ & $(0.000)$ & $(0.008)$ & $(0.000)$ & $(0.000)$ \\
Risk & 0.137 & 0.132 & 0.125 & 0.000 & -0.000 & 0.001 \\
& $(0.071)$ & $(0.065)$ & $(0.078)$ & $(0.995)$ & $(0.962)$ & $(0.845)$ \\
Cap & -7.546 & -3.411 & -2.769 & 2.109 & 1.763 & 1.738 \\
& $(0.027)$ & $(0.264)$ & $(0.343)$ & $(0.000)$ & $(0.000)$ & $(0.000)$ \\
Cons & 15.668 & 10.798 & 11.404 & -0.490 & -0.182 & -0.182 \\
Obs & $(0.000)$ & $(0.000)$ & $(0.000)$ & $(0.121)$ & $(0.456)$ & $(0.462)$ \\
R2 & 1,240 & 1,240 & 1,240 & 1240 & 1,240 & 1,240 \\
Hansen test & 0.216 & 0.297 & 0.313 & 0.256 & 0.335 & 0.339 \\
\hline \hline
\end{tabular}

Notes: p-value are reported in parentheses. *, ** and *** denote statistical significance at $10 \%, 5 \%$ and $1 \%$ respectively.

\subsection{Quantile regression}

In table 7-panel A, we apply quantile regression to consider heterogeneous responses to gender leadership. Intuitively, high and low-performing firms $\left(\mathrm{Q} 75: 75^{\text {th }}\right.$ percentile and Q25: $25^{\text {th }}$ percentile) might respond differently to female leadership. Besides, the Breusch-Pagan/CoolWeisberg tests justify the validity of all quantile regressions outcomes. We find that in highperforming firms (Q75), the non-executive female director has a positive association with ROA, which is consistent with the view that female non-executive directors may bring effective collaboration among all board members leading to an increase in accounting return (Adams \& Funk, 2012).

Conversely, Tobin's Q is negatively correlated with female executive directors and gender diversity in the boardroom supporting $\mathbf{H 2 a}$ and $\mathbf{H 3 a}$. These results imply that the market underestimates the growth opportunities of low-performing firms since they increase gender diversity in managerial levels (Wernerfelt \& Montgomery, 1988; Gordini \& Rancati, 2017). Furthermore, the negative impact of female executive directors on Tobin's $Q$ in low-performing firms might be explained by the stereotypes from feminism theory since women would contribute to firm less than their male counterparts (Fischer et al., 1993; Alowaihan, 2004).

In addition, we find evidence that the total number of executive directors' decreases/increases ROA and Tobin's Q in low/high-performing firms that is consistent with Eisenberg et al. (1998). The association of firm size and firm performance is somewhat inconclusive. The firm's size makes a positive impact on performance in high-performing firms, whereas negative influence on low-performing firms.

Table 7. Quantile regression of performance and female leadership in the firms

\begin{tabular}{lrrrrr}
\hline \hline & \multicolumn{5}{l}{ Panel A - High-performing firms Q75 } \\
\cline { 2 - 6 } & \multicolumn{7}{l}{ ROA } & $(1)$ & $(3)$ & Tobin's Q & $(4)$ & $(5)$ \\
\cline { 2 - 6 } & 0.763 & & 0.059 & & \\
$\mathrm{Fc}$ & $(0.365)$ & 1.561 & $(0.872)$ & 0.121 \\
\\
$\mathrm{Fe}$ & & $(0.240)$ & & $(0.200)$
\end{tabular}




\begin{tabular}{|c|c|c|c|c|c|c|}
\hline Fne & \multicolumn{3}{|c|}{$\begin{array}{c}\text { 2.868* } \\
(0.055)\end{array}$} & \multicolumn{3}{|c|}{$\begin{array}{r}0.223 \\
(0.813)\end{array}$} \\
\hline \multirow{2}{*}{$\mathrm{Fb}$} & & & 1.505 & & & 0.111 \\
\hline & & & $(0.202)$ & & & $(0.395)$ \\
\hline \multirow{2}{*}{$\mathrm{Fm}$} & & & 0.116 & & & 0.009 \\
\hline & & & $(0.909)$ & & & $(0.491)$ \\
\hline \multirow{2}{*}{ Exe } & 0.699 & 0.953 & 0.688 & 0.054 & 0.074 & 0.051 \\
\hline & $(0.001)$ & $(0.003)$ & $(0.002)$ & $(0.000)$ & $(0.000)$ & $(0.000)$ \\
\hline \multirow{2}{*}{ Man } & 0.017 & 0.017 & 0.031 & 0.001 & 0.001 & 0.002 \\
\hline & $(0.839)$ & $(0.782)$ & $(0.935)$ & $(0.068)$ & $(0.035)$ & $(0.077)$ \\
\hline \multirow{2}{*}{$\mathrm{Fa}$} & 0.039 & 0.037 & 0.038 & 0.003 & 0.0029 & 0.003 \\
\hline & $(0.000)$ & $(0.000)$ & $(0.000)$ & $(0.000)$ & $(0.000)$ & $(0.000)$ \\
\hline \multirow{2}{*}{ Size } & 0.129 & 0.125 & 0.128 & 0.010 & 0.010 & 0.009 \\
\hline & $(0.000)$ & $(0.000)$ & $(0.000)$ & $(0.000)$ & $(0.000)$ & $(0.000)$ \\
\hline \multirow{2}{*}{ Age } & 0.220 & 0.215 & 0.218 & 0.017 & 0.017 & 0.016 \\
\hline & $(0.002)$ & $(0.014)$ & $(0.014)$ & $(0.001)$ & $(0.000)$ & $(0.000)$ \\
\hline \multirow{2}{*}{ Risk } & 0.129 & 0.126 & 0.127 & 0.010 & 0.010 & 0.010 \\
\hline & $(0.704)$ & $(0.475)$ & $(0.577)$ & $(0.303)$ & $(0.261)$ & $(0.236)$ \\
\hline \multirow{2}{*}{$\mathrm{Be}$} & 0.062 & 0.060 & 0.061 & 0.005 & 0.005 & 0.004 \\
\hline & $(0.000)$ & $(0.000)$ & $(0.000)$ & $(0.000)$ & $(0.000)$ & $(0.000)$ \\
\hline \multirow{2}{*}{ Cons } & 1.567 & 1.602 & 1.545 & 0.120 & 0.124 & 0.114 \\
\hline & $(0.000)$ & $(0.000)$ & $(0.000)$ & $(0.000)$ & $(0.000)$ & $(0.000)$ \\
\hline Obs & 1,240 & 1,240 & 1,240 & 1,240 & 1,240 & 1,240 \\
\hline \multirow[t]{4}{*}{ Seudo-R2 } & 0.2308 & 0.2352 & 0.2344 & 0.2766 & 0.2778 & 0.2781 \\
\hline & \multicolumn{6}{|c|}{ Panel A - High-performing firms Q75 } \\
\hline & \multicolumn{3}{|l|}{ ROA } & \multicolumn{3}{|c|}{ Tobin's Q } \\
\hline & $(7)$ & $(8)$ & $(9)$ & $(10)$ & $(11)$ & $(12)$ \\
\hline \multirow{2}{*}{$\mathrm{Fc}$} & -0.014 & & & 0.007 & & \\
\hline & $(0.895)$ & & & $(0.629)$ & & \\
\hline \multirow{2}{*}{$\mathrm{Fe}$} & & -0.070 & & & $-0.111 * * *$ & \\
\hline & & $(0.765)$ & & & $(0.000)$ & \\
\hline \multirow{2}{*}{ Fne } & & 0.08637 & & & 0.033 & \\
\hline & & $(0.840)$ & & & $(0.485)$ & \\
\hline \multirow{2}{*}{$\mathrm{Fb}$} & & & -0.030 & & & $-0.059 * *$ \\
\hline & & & $(0.896)$ & & & $(\mathbf{0 . 0 2 1})$ \\
\hline & & & 0.002 & & & $-0.004 *$ \\
\hline $\mathrm{Fm}$ & & & $(0.920)$ & & & $(0.063)$ \\
\hline & -0.056 & -0.018 & -0.046 & -0.049 & -0.016 & -0.042 \\
\hline Exe & $(0.569)$ & $(0.897)$ & $(0.666)$ & $(0.000)$ & $(0.308)$ & $(0.000)$ \\
\hline & 0.003 & 0.002 & 0.002 & 0.001 & 0.000 & 0.001 \\
\hline Man & $(0.273)$ & $(0.339)$ & $(0.624)$ & $(0.105)$ & $(0.073)$ & $(0.04)$ \\
\hline $\mathrm{Fa}_{3}$ & -0.007 & -0.007 & -0.007 & -0.008 & -0.008 & -0.008 \\
\hline $\mathrm{Fa}$ & $(0.213)$ & $(0.206)$ & $(0.253)$ & $(0.000)$ & $(0.000)$ & $(0.000)$ \\
\hline & -0.896 & -0.894 & -0.896 & -0.018 & -0.017 & -0.017 \\
\hline Size & $(0.000)$ & $(0.000)$ & $(0.000)$ & $(0.000)$ & $(0.000)$ & $(0.000)$ \\
\hline & -0.007 & -0.009 & -0.005 & -0.016 & -0.015 & -0.015 \\
\hline Age & $(0.809)$ & $(0.770)$ & $(0.874)$ & $(0.000)$ & $(0.000)$ & $(0.000)$ \\
\hline & 0.061 & 0.061 & 0.061 & 0.001 & 0.000 & 0.001 \\
\hline Risk & $(0.001)$ & $(0.001)$ & $(0.002)$ & $(0.770)$ & $(0.828)$ & $(0.552)$ \\
\hline & 0.885 & 0.886 & 0.887 & 0.003 & 0.003 & 0.003 \\
\hline $\mathrm{Be}$ & $(0.000)$ & $(0.000)$ & $(0.000)$ & $(0.002)$ & $(0.001)$ & (0.003) \\
\hline
\end{tabular}




\begin{tabular}{lrrrrrr} 
Cons & 5.373 & 5.337 & 5.360 & 0.486 & 0.457 & 0.488 \\
& $(0.000)$ & $(0.000)$ & $(0.000)$ & $(0.000)$ & $(0.000)$ & $(0.000)$ \\
Obs & 1,240 & 1,240 & 1,240 & 1,240 & 1,240 & 1,240 \\
Seudo-R2 & 0.2743 & 0.2744 & 0.2743 & 0.0847 & 0.0889 & 0.0879 \\
\hline \hline
\end{tabular}

Notes: This table reports OLS quantile regressions. Q75 at the $75^{\text {th }}$ percentile and Q25 at $25^{\text {th }}$ percentile. Standard errors are clustered by firm with p-value are reported in parentheses. $* * *$ and $* * *$ denote statistical significance at $10 \%, 5 \%$ and $1 \%$ respectively.

\section{CONCLUSION}

The gender stereotype that women could not be efficient leaders has existed for a long time. That viewpoint faces many criticisms from society and the academic field. Women have increasingly played an essential role in sustainable development involving cohesive social components. In the literature, the role of female executives all over the world gains a lot of attraction from the scholars (Gordini \& Rancati, 2017). However, the association of female leadership towards firm performance is still argued. In this paper, we argued that in order to understand the impact of female leadership on firm's financial performance, it is essential to distinguish female directors' role in alternative managerial levels at/in greater context such as WE market.

In coherence with our theoretical predictions, we generally acknowledge the negative impact of female leadership in Western European financial institutions on firm performance. In particular, our findings indicate that the appearance of women in top executive, chairperson, for instance, significantly reduces Tobin's Q. It means that the firms with chairwoman have poor investments, and market participants may want them to pay more dividends to cover for the low future growth opportunities (Eckbo, 2008). Besides, we find a negative correlation between ROA and the proportion of female executive directors. That negative effect is probably explained by feminism or principal-agent theory. Specifically, the feminism theory specifies the negative impact of a female executive on firm performance comes from the more challengers that female leaders face that males do not (Eagly, 2007); whereas principal-agent theory explained that the intense overmonitoring and intervention behavior derived from women in leadership positions would damage firm financial performance (Adams \& Ferreira, 2009). We also find the negative influence of total female directors on ROA that indicates the limitation of female leadership in providing an effective investment to create firm benefits. To further our analysis, we distinguish the role of female leadership in low/high-performing firms. Interestingly, high-performing firms' growth opportunity is damaged by female executive directors and women's appearance in the boardroom.

Besides, we document that the relationship between female leadership and firm financial performance is more critical considering the context of WE financial sector. We suppose that although WE region has transferred into the economic recovery period since 2013 (Tucaa, 2014; Amorello \& Huber, 2014), the negative consequences from financial crisis to the financial sector are still remained (Benczes \& Szent-Ivanyi, 2015). The breakdown in corporate governance regimes and market disciplines requires the new regulations advocating such market-based remedies as over-monitoring investors and more significant control over executive remuneration (Avgouleas \& Cullen, 2014). Thus, the new tight rules of hedging funds and consumer protection may reduce the investment capabilities of financial institutions. In that context, although female leaderships are mentioned to reduce the agency cost and increase firm value, their contributions to 
firm performance and growth opportunities may be limited due to their conservative decisions in investment (Tran et al., 2020). Furthermore, the appearance of women may not be relevant to a firm's value-enhancing strategies, but firms may positively be responding to outside pressure and satisfy the social requirement on gender equality in the boardroom (Farrell \& Hersch, 2005). Hence, women tend to adopt less-risk strategies rather than maximizing managerial incentives, which might reduce firm's final performance.

Our study collectively fulfills the relevant literature of board gender diversity by providing empirical evidence of the role of female leadership towards firm financial performance in Western Europe. However, several limitations might be improved in future work. First, future research may consider different econometric approaches to verify female leadership's role in alternative managerial levels. Second, future studies may include other countries or regions to extend our findings. Finally, our study consists of the period of the economic recovery of Western European countries, the different time frames may be considered.

\section{ACKNOWLEDGEMENT}

Thanks to the suggestions and comments of two anonymous reviewers and Prof. Evan Lau, whose great job improves the quality of this paper. However, all the faults and deficiencies belong to the authors.

\section{REFERENCES}

Abatecola, G. (2014). Research in organizational evolution. What comes next?. European Management Journal, 32(3), 434-443.

Adams, R. B., \& Ferreira, D. (2009). Women in the boardroom and their impact on governance and performance. Journal of financial economics, 94(2), 291-309.

Adams, R. B., \& Funk, P. (2012). Beyond the glass ceiling: Does gender matter?. Management science, 58(2), 219-235.

Adams, R. B., de Haan, J., Terjesen, S., \& van Ees, H. (2015). Board diversity: Moving the field forward. Corporate Governance: An International Review, 23(2), 77-82.

Alowaihan, A. K. (2004). Gender and business performance of Kuwaiti small firms: A comparative approach. International Journal of Commerce and Management, 14(3-4), 69-83.

Ammann, M., Oesch, D., \& Schmid, M. M. (2011). Corporate governance and firm value: International evidence. Journal of Empirical Finance, 18(1), 36-55.

Amorello, L., \& Huber, S. (2014). Recovery Planning: A New Valuable Corporate Governance Framework for Credit Institutions. Law and Economics Yearly Review, 3(2), 296-317.

Amran, N. A. (2011). The effect of owner's gender and age to firm performance: A review on Malaysian public listed family businesses. Journal of global business and economics, 2(1), 104-116.

Avgouleas, E., \& Cullen, J. (2014). Market discipline and EU corporate governance reform in the banking sector: Merits, fallacies, and cognitive boundaries. Journal of Law and Society, 41(1), 28-50. 
Barney, J. (1991). Firm resources and sustained competitive advantage. Journal of management, 17(1), 99-120.

Benczes, I., \& Szent-Ivanyi, B. (2015). The European economy in 2014: Fragile recovery and convergence. J. Common Mkt. Stud., 53, 162.

Bennouri, M., Chtioui, T., Nagati, H., \& Nekhili, M. (2018). Female board directorship and firm performance: What really matters?. Journal of Banking \& Finance, 88, 267-291.

Berle, A., \& Means, G. (1932). Private property and the modern corporation. New York: Macmillan.

Bonn, I. (2004). Board structure and firm performance: Evidence from Australia. Journal of Management \& Organization, 10(1), 14-24.

Campbell, K., \& Mínguez-Vera, A. (2008). Gender diversity in the boardroom and firm financial performance. Journal of business ethics, 83(3), 435-451.

Carter, D. A., Simkins, B. J., \& Simpson, W. G. (2003). Corporate governance, board diversity, and firm value. Financial review, 38(1), 33-53.

Carter, D. A., D'Souza, F., Simkins, B. J., \& Simpson, W. G. (2010). The gender and ethnic diversity of US boards and board committees and firm financial performance. Corporate Governance: An International Review, 18(5), 396-414.

Caprio, G., Laeven, L., \& Levine, R. (2007). Governance and bank valuation. Journal of Financial Intermediation, 16(4), 584-617.

De Andres, P., \& Vallelado, E. (2008). Corporate governance in banking: The role of the board of directors. Journal of banking \& finance, 32(12), 2570-2580.

Eagly, A. H. (2007). Female leadership advantage and disadvantage: Resolving the contradictions. Psychology of women quarterly, 31(1), 1-12.

Eagly, A. H., \& Karau, S. J. (2002). Role congruity theory of prejudice toward female leaders. Psychological review, 109(3), 573-598.

Eckbo, B. E. (Ed.). (2008). Handbook of empirical corporate finance set. Elsevier.

Eisenberg, T., Sundgren, S., \& Wells, M. T. (1998). Larger board size and decreasing firm value in small firms. Journal of financial economics, 48(1), 35-54.

Erhardt, N. L., Werbel, J. D., \& Shrader, C. B. (2003). Board of director diversity and firm financial performance. Corporate governance: An international review, 11(2), 102-111.

Fairlie, R. W., \& Robb, A. M. (2009). Gender differences in business performance: evidence from the Characteristics of Business Owners survey. Small Business Economics, 33(4), 375.

Farrell, K. A., \& Hersch, P. L. (2005). Additions to corporate boards: The effect of gender. Journal of Corporate finance, 11(1-2), 85-106.

Fischer, E. M., Reuber, A. R., \& Dyke, L. S. (1993). A theoretical overview and extension of research on sex, gender, and entrepreneurship. Journal of business venturing, 8(2), 151-168.

Gordini, N., \& Rancati, E. (2017). Gender diversity in the Italian boardroom and firm financial performance. Management Research Review, 40(1), 75-94.

Hausman, J. A. (1978). Specification tests in econometrics. Econometrica: Journal of the econometric society, 1251-1271.

Hasan, M. S., Rahman, R. A., \& Hossain, S. Z. (2014). Monitoring family performance: family ownership and corporate governance structure in Bangladesh. Procedia-Social and Behavioral Sciences, 145, 103-109.

Hermalin, B. E., \& Weisbach, M. S. (1988). The determinants of board composition. RAND Journal of Economics, 19(4), 589-606. 
Hillman, A. J., Cannella Jr, A. A., \& Harris, I. C. (2002). Women and racial minorities in the boardroom: how do directors differ?. Journal of management, 28(6), 747-763.

Hillman, A. J., Shropshire, C., \& Cannella Jr, A. A. (2007). Organizational predictors of women on corporate boards. Academy of Management Journal, 50(4), 941-952.

Hoobler, J. M., Masterson, C. R., Nkomo, S. M., \& Michel, E. J. (2018). The business case for women leaders: Meta-analysis, research critique, and path forward. Journal of Management, 44(6), 2473-2499.

Hsu, C. S., Kuo, L., \& Chang, B. G. (2013). Gender difference in profit performance-evidence from the owners of small public accounting practices in Taiwan. Asian Journal of Finance \& Accounting, 5(1), 140-159.

Ionascu, M., Ionascu, I., Sacarin, M., \& Minu, M. (2018). Women on boards and financial performance: Evidence from a European emerging market. Sustainability, 10(1644), 1-18.

Isidro, H., \& Sobral, M. (2015). The effects of women on corporate boards on firm value, financial performance, and ethical and social compliance. Journal of Business Ethics, 132(1), 1-19.

Joecks, J., Pull, K., \& Vetter, K. (2013). Gender diversity in the boardroom and firm performance: What exactly constitutes a "critical mass?". Journal of business ethics, 118(1), 61-72.

Jourova, V. (2016). Gender balance on corporate boards: Europe is cracking the glass ceiling. Brussels: European Commission.

Kochan, T., Bezrukova, K., Ely, R., Jackson, S., Joshi, A., Jehn, K., Leonard, J., Levine, D., \& Thomas, D. (2003). The effects of diversity on business performance: Report of the diversity research network. Human Resources Management, 42(1), 3-21.

Li, H., \& Chen, P. (2018). Board gender diversity and firm performance: The moderating role of firm size. Business Ethics: A European Review, 27(4), 294-308.

Marinova, J., Plantenga, J., \& Remery, C. (2016). Gender diversity and firm performance: Evidence from Dutch and Danish boardrooms. The International Journal of Human Resource Management, 27(15), 1777-1790.

Masulis, R. W., Wang, C., \& Xie, F. (2012). Globalizing the boardroom-The effects of foreign directors on corporate governance and firm performance. Journal of Accounting and Economics, 53(3), 527-554.

Mukarram, S. S., Saeed, A., Hammoudeh, S., \& Raziq, M. M. (2018). Women on Indian boards and market performance: a role-congruity theory perspective. Asian Business \& Management, 17(1), 4-36.

Nanka-Bruce, D. (2011). Corporate governance mechanisms and firm efficiency. International Journal of Business and Management, 6(5), 28-40.

Nguyen, T., Locke, S., \& Reddy, K. (2015). Does boardroom gender diversity matter? Evidence from a transitional economy. International Review of Economics \& Finance, 37, 184-202.

Peij, S. C., Bezemer, P. J., \& Maassen, G. F. (2012). The effectiveness of supervisory boards: an exploratory study of challenges in Dutch boardrooms. International Journal of Business Governance and Ethics, 7(3), 191-208.

Peni, E., \& Vähämaa, S. (2012). Did good corporate governance improve bank performance during the financial crisis?. Journal of Financial Services Research, 41(1-2), 19-35.

Peterson, C. A., \& Philpot, J. (2007). Women's roles on US Fortune 500 boards: Director expertise and committee memberships. Journal of Business Ethics, 72(2), 177-196.

Poletti-Hughes, J., \& Briano-Turrent, G. C. (2019). Gender diversity on the board of directors and corporate risk: A behavioural agency theory perspective. International Review of Financial Analysis, 62, 80-90. 
Reinert, R. M., Weigert, F., \& Winnefeld, C. H. (2016). Does female management influence firm performance? Evidence from Luxembourg banks. Financial Markets and Portfolio Management, 30(2), 113-136.

Rose, C. (2007). Does female board representation influence firm performance? The Danish evidence. Corporate Governance: An International Review, 15(2), 404-413.

Shrader, C. B., Blackburn, V. B., \& Iles, P. (1997). Women in management and firm financial performance: An exploratory study. Journal of managerial issues, IX(3), 355-372.

Singhathep, T., \& Pholphirul, P. (2015). Female CEOs, firm performance, and firm development: Evidence from Thai manufacturers. Gender, Technology and Development, 19(3), 320-345.

Tate, G., \& Yang, L. (2015). Female leadership and gender equity: Evidence from plant closure. Journal of Financial Economics, 117(1), 77-97.

Terjesen, S., Aguilera, R. V., \& Lorenz, R. (2015). Legislating a woman's seat on the board: Institutional factors driving gender quotas for boards of directors. Journal of Business Ethics, 128(2), 233-251.

Tran, C. D., Phung, M. T., Yang, F. J., \& Wang, Y. H. (2020). The Role of Gender Diversity in Downside Risk: Empirical Evidence from Vietnamese Listed Firms. Mathematics, 8(933), 122.

Tucaa, S. (2014). The Stage of the European Unions Economic Recovery. Procedia Economics and Finance, 16, 374-380.

Vafaei, A., Ahmed, K., \& Mather, P. (2015). Board diversity and financial performance in the top 500 Australian firms. Australian Accounting Review, 25(4), 413-427.

Villalonga, B., \& Amit, R. (2006). How do family ownership, control and management affect firm value?. Journal of financial Economics, 80(2), 385-417.

Wang, J. Y., Tran, C. D., \& Wu, W. L. (2019). Role of Board Structure in Financial Institutions: Evidence from Western Europe. Journal of Accounting, Finance \& Management Strategy, 14(2), 113-151.

Wernerfelt, B., \& Montgomery, C. A. (1988). Tobin's q and the importance of focus in firm performance. The American Economic Review, 78(1), 246-250.

Wintoki, M. B., Linck, J. S., \& Netter, J. M. (2012). Endogeneity and the dynamics of internal corporate governance. Journal of Financial Economics, 105(3), 581-606.

Zhang, C. Z., Guo, Q., \& Mu, X. (2016). How female executives affect firm performance? A multiapproach perspective. Advances in Economics and Business, 4(7), 351-365. 